\title{
Article
}

\section{An empirical assessment of factors affecting the brand-building effectiveness of sponsorship}

\author{
Donlan, Leah K
}

Available at http://clok.uclan.ac.uk/7179/

Donlan, Leah K ORCID: 0000-0002-1320-2803 (2013) An empirical assessment of factors affecting the brand-building effectiveness of sponsorship. Sport, Business and Management: An International Journal, - (-). ISSN 2042-678X (Submitted)

It is advisable to refer to the publisher's version if you intend to cite from the work.

For more information about UCLan's research in this area go to http://www.uclan.ac.uk/researchgroups/ and search for < name of research Group>.

For information about Research generally at UCLan please go to http://www.uclan.ac.uk/research/

All outputs in CLoK are protected by Intellectual Property Rights law, including Copyright law. Copyright, IPR and Moral Rights for the works on this site are retained by the individual authors and/or other copyright owners. Terms and conditions for use of this material are defined in the policies page.

\section{CLoK}

Central Lancashire online Knowledge www.clok.uclan.ac.uk

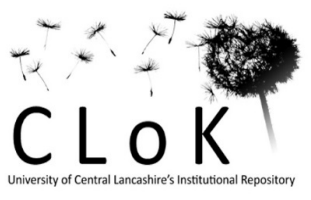




\section{Abstract}

Purpose: This study assesses, in two different live sponsorship environments, the contribution of sponsorship to consumer-based brand equity.

Design/methodology/approach: The study adopts a quantitative survey methodology, employing self-administered questionnaires at two UK sporting events (athletics and cricket). To isolate the impact of sponsorship, questionnaires were also distributed to comparison sample groups not exposed to the sponsorship activities. The elements of consumer-based brand equity are operationalised in line with Aaker's (1996) brand equity measurement tool.

Findings: Sponsorship can be an appropriate vehicle through which to build consumer-based brand equity; however brand building success is not guaranteed and is subject to a range of factors impacting upon particular sponsorships, including strength of the sponsor-event link, leverage activities and clutter. The most successful sponsorship displayed marked contributions to building brand associations, perceived quality and brand loyalty. However, the presence of sponsorship clutter in particular was found to impact negatively upon the perception of quality transferred to a brand through sponsorship.

Research limitations/implications: The use of live event settings limits the ability to tightly control all variables; therefore replication of this study using experimental methodologies is recommended. Nonetheless, findings indicate managers should consider the above mentioned contextual factors when selecting sponsorships in order to maximise sponsorship success.

Originality/value: This study explores the contribution of sports sponsorship to consumer-based brand equity in live sponsorship settings, addressing concerns over 
the generalizability of previous experimental studies. Equally, this study compares the brand equity-building effectiveness of sponsorship for two sponsors, which differ on a range of contextual factors that impact upon sponsorship success.

Keywords: sponsorship; effectiveness; brand associations; brand equity; clutter 


\section{An empirical assessment of factors affecting the brand-building effectiveness of sponsorship}

\subsection{Introduction}

Recent years have seen exponential growth in sports sponsorship, with worldwide expenditure reaching $\$ 51.1$ billion in 2012 (IEG, 2013). Growth in sponsorship expenditures has been mirrored by an increasing focus among academics on examining a wide range of areas (Walliser, 2003) relating to sponsorship practices (e.g. Poon and Prendergast, 2006), objectives (e.g. Hartland et al, 2005; Abratt et al, 1987) and notably the measurement of sponsorship effectiveness (e.g. Pope et al, 2009; Weeks et al, 2008; Harvey, 2001).

The objectives pursued through sponsorship differ between sponsors of different product categories and individual sponsors. Nevertheless, it is widely held that commonly sought objectives include awareness (Verity, 2002); image/positioning benefits (Hartland et al, 2005); corporate hospitality opportunities (Quester, 1997); and, to a lesser extent, sales (Tomasini et al, 2004). As such, there is a clear focus among sponsors on using sponsorship for brand building purposes (Hartland et al, 2005), distinct from historical notions of sponsorship as synonymous with philanthropy or patronage. Considerable previous research has explored a range of factors impacting upon sponsorship effectiveness, including the role of involvement (Grohs and Reisinger, 2005), sponsor prominence (Johar and Pham, 1999), clutter (Cornwell et al, 2005), fit (Simmons and Becker-Olsen, 2006) and leverage activities (Papadimitriou and Apostolopoulou, 2009). However, the focus of many such studies 
has been on measuring sponsorship effectiveness in terms of brand awareness and/or brand associations. Therefore, there are considerable gaps in our understanding of the wider role of sponsorship in building other elements of brand equity.

The prominence of brand equity and its growing role in determining sponsorship objectives makes consumer-based brand equity a relevant and interesting framework with which to assess sponsorship effectiveness. Much previous work has explored the impact of other communications tools such as advertising (Kim, 2001) and sales promotions (Palazón-Vidal and Delgado-Ballester, 2005) on brand equity and there have been several studies, which found that managers perceive sponsorship to have a positive impact on elements of brand equity (Cornwell et al, 2001; Henseler et al, 2011). In line with the growing need to investigate the effectiveness of sponsorship through the use of theoretical frameworks (Cornwell, 2008), this study assesses, from a consumer perspective, the contribution made by sponsorship to consumer-based brand equity and explores the differential factors affecting sponsorship's brand building ability.

This study is different in that, in a departure from many previous experimental investigations (e.g. Johar and Pham, 1999; Pham and Johar, 2001; Washburn and Plank, 2002), sponsorship effectiveness is assessed in live sponsorship settings. The use of live sponsorship settings addresses concerns raised about the generalizability of previous experimental studies, as consumer responses to sponsorship are obtained under prevailing market and environmental conditions. In reality, a combination of factors (some controllable by the sponsor, e.g. activation activities, others not controllable, e.g. promotional activities of competitors, weather conditions) is always 
impacting on consumer response to sponsorship stimuli; thus, differences in sponsorship effectiveness between brands are examined in real sponsorship environments, rather than being artificially isolated.

Not only does this study build upon previous investigations into the contribution of sponsorship to elements of brand equity, but it compares two sponsors which differ on contextual factors impacting upon potential sponsorship success, such as leverage activities and clutter. The names of sponsors are concealed to prevent the revealing of potentially commercially sensitive information. This anonymity was required as a condition by both brands when allowing the researchers access to the sponsored events for data collection. In comparing effectiveness across different sponsorship environments, this paper draws conclusions regarding the optimal conditions for sponsorship success. As such, the findings presented in this paper not only inform the academic understanding of how sponsorship works but also provide guidelines for practitioners faced with the task of selecting and implementing appropriate sponsorship-related brand communication strategies.

\subsection{Literature Review and Development of Hypotheses}

A conceptualisation of consumer-based brand equity is proposed by Aaker (1991:15), who suggests that:

"brand equity is a set of brand assets and liabilities linked to a brand, its name and symbol, that add to or subtract from the value provided by a product or service to a firm and/or that firm's customer." 
Within this framework, Aaker considers brand equity as comprising brand awareness, brand associations, perceived quality, brand loyalty and other proprietary brand assets, which include trademarks and channel relationships and are internal to the brand owner. In line with his conceptualisation of consumer-based brand equity, Aaker (1996) developed a multi-dimensional tool to facilitate brand equity measurement. This paper adopts the model of consumer-based brand equity put forward by Aaker (1991) as the conceptual framework within which to measure the contribution of sports sponsorship.

While a comprehensive investigation of the impact of sports sponsorship on consumer-based brand equity has not previously been carried out, significant contributions have been made examining the role of sponsorship in developing individual elements of brand equity, notably awareness and associations. A positive relationship between sponsorship exposure and brand awareness has been found (Quester, 1997; Bennett, 1999; Rines, 2002), suggesting that sponsorship is a legitimate tool for brands wanting to gain exposure in order to build awareness. A primary means of gaining brand awareness has traditionally been the use of on-site signage, with McCook et al (1997) identifying signage/visibility as an important criterion for brands when considering sponsorship opportunities. However, with a growing focus on brand objectives going beyond awareness, the use of signage as a sole sponsorship communications vehicle is questionable, particularly in the growing clutter of the contemporary sports sponsorship environment (Skildum-Reid, 2003). The presence of sponsorship clutter, defined as a high level of competing communications, has been found to negatively impact on sponsorship effectiveness 
(Cornwell et al, 2005). Equally, Maxwell and Lough (2009) question the importance of signage exposure and suggest that sponsorship clutter means that consumers are exposed to so many sponsor messages that the majority of them are simply noise.

The avoidance of clutter is an important factor to consider for brands in evaluating sponsorship opportunities, with Copeland et al (1996) identifying exclusivity as an important sponsorship decision-making criterion. While not all properties offer exclusivity, if sponsorship is to be exploited as a source of sustainable competitive advantage (Amis et al, 1997), then sponsorships should be selected for their ability to act as a point of competitive differentiation. As important as the avoidance of clutter when making sponsorship decisions is the potential of sponsorships to offer opportunities to exploit or leverage the sponsorship association (Papadimitriou and Apostolopoulou, 2009). Activating a sponsorship, for example through associated advertising, is crucial to the sponsorship's success at influencing consumer attitudes (Mason, 2005) and ultimately building brand equity (Tripodi and Hurons, 2009;

Cornwell et al, 2005).

In an extension to the work on awareness, many studies have investigated sponsorship's role in building brand associations (Roy and Cornwell, 1999; Nufer and Bühler, 2010), including perceived quality. Whilst awareness is a valid objective for many sponsors, effectiveness of the sponsorship will be enhanced if spectators go beyond mere awareness and image transfer takes place (Roy and Cornwell, 2004). An important determinant of sponsorship's ability to build brand associations is the level of fit between the sponsoring brand and the sponsored property (Grohs and Reisinger, 2005; Martensen et al, 2007). Theoretical models of image transfer have 
proposed sponsor-event fit as playing an important role (Gwinner, 1997), using both Schema theory and the Associative Network theory (Smith, 2004) to explain how associations are transferred from sponsored properties to brands. Equally, BeckerOlsen and Hill (2006) identified a positive impact of fit on sponsor brand equity. Moving beyond mere associations, fit has also been found to impact on consumer attitude towards sponsoring brands (Weeks et al, 2008) and even purchase intention (Dees et al, 2010). In contrast, when examining managerial perceptions, while Henseler et al (2007) found that sponsorship can contribute significantly to brand equity, they posit that low levels of fit can be compensated for by increasing the level of investment in the sponsorship.

Another factor impacting sponsorship effectiveness is the duration of a sponsorship arrangement (Smith, 2004). Brand equity is not built in the short-term (Anantachart, 2005) and therefore building brand equity through sponsorship implies the need for a long-term commitment. Nickell et al (2011) posit that the longer the relationship between a sponsor and a sponsored property, the stronger will be both consumer affect and connation towards the sponsoring brand. From a consumer perspective, greater familiarity (built up over time) with a sponsor and/or a sponsored event allows for the development of more elaborate cognitive structures and more efficient processing of product/brand stimuli (Cornwell et al, 2005). Therefore, as consumers become more familiar with a sponsor-sponsored property pairing, so the ease of formation of associations related to the sponsoring brand increases. Such a contention supports the resource-based view of sponsorship (Amis et al, 1997), with long-term sponsorship becoming a source of competitive advantage as sponsors build up a set of resources which are not easily imitable by competitors. Both sponsorships explored 
in this study have lasted over several years; therefore it is reasonable to suggest that the sponsorships will have a positive impact on brand associations.

Compared with the level of interest in sponsorship's contribution to overall image dimensions, less attention has been paid to the effect of sponsorship on perceived quality. Nonetheless, many general image-based studies have included a basic measure of quality within the image dimensions (e.g. Javalgi et al, 1994). Supporting empirical evidence comes from a survey by Total Research, which found that sponsors of the Euro 96 football tournament experienced the greatest increase in perceived quality ratings (Busby, 1997). Similarly, VISA saw a 50\% increase in perceptions of the brand as the overall best payment card following its Olympic sponsorship (Payne, 2005). Therefore, this study proposes the following hypotheses relating to the ability of sponsorship to build such associations:

$\mathbf{H}_{1}$ : Exposure to sports sponsorship will have a positive impact upon brand associations for sponsoring brands.

$\mathbf{H}_{2}$ : Exposure to sports sponsorship will have a positive impact on perceived quality ratings of sponsoring brands.

The empirical evidence indicates that sponsorship is capable of contributing to imagebased objectives. However, there is a comparative paucity of studies exploring the relationship between sponsorship and brand loyalty; as such there is little consensus on the role of sponsorship in building loyalty. Some empirical support has been found for the ability of sponsorship to positively impact upon purchase intention (Pope and Voges, 2000; Performance Research, 2003; Dees et al, 2008); however in 
an experimental context, Hoek et al (1997) found no discernible impact on reported intention to purchase products/services from sponsors.

Equally, some studies have provided evidence of sponsorship's ability to increase brand loyalty, particularly in the case of NASCAR racing (Levin et al, 2004). In another study relating to NASCAR, Sirgy et al (2008) found that self-congruity with sponsored sports events positively impacts sponsor brand loyalty when customers are aware of the sponsorship and have some degree of involvement with the sponsored event. Nonetheless, despite the importance of customer loyalty and retention (Helgesen, 2006; Too et al, 2001), studies of this nature are very much in the minority in the wider context of sponsorship research. Therefore, by examining the impact of sponsorship on brand loyalty across two sponsorship contexts, this study advances our understanding of the wider brand-building role of sponsorship. Consequently, the following hypothesis is proposed:

$\mathbf{H}_{3}$ : Exposure to sports sponsorship will have a positive impact upon brand loyalty towards sponsoring brands.

\subsection{Methodology}

In order to test the above hypotheses, and in line with much previous marketing research (Rindfleisch et al, 2008), this study employed a cross-sectional survey methodology, comparing brand equity for the sponsoring brands among both those exposed to the sponsorships and samples from the wider UK population. A selfadministered questionnaire was distributed at two international athletics meetings (combined event sample $\mathrm{n}=206$ ) and two domestic one-day cricket matches 
(combined event sample $\mathrm{n}=106$ ), and among comparison samples not present at the events (athletics comparison sample $n=141$, cricket comparison sample $n=102$ ).

Both events were sponsored by well-known financial services brands, with the athletics sponsor being the largest and dominant sponsor of the sport in the UK, sponsoring seven meetings throughout the year. Both athletics meetings were annual, international elite (i.e. world class) level competitions, which had been sponsored by the brand in question for five years prior to the data collection. In contrast, at the time of the study, there were seven sponsors involved with cricket competitions in the UK, five of which came from the financial services sector, along with sponsors for each county team and the England national teams. The cricket matches formed part of a national competition between first-class county teams (i.e. highest level professional domestic cricket). The cricket sponsorship, which was in its second year, thus provides an example of a cluttered sponsorship environment, which has implications for the ability of a single sponsor to communicate its message. Therefore, cricket was selected to capture this characteristic of the sponsorship environment.

While having a higher profile than athletics, cricket is not as popular as a spectator sport as the main UK sports of football and rugby (Mintel, 2011a). Therefore, the decision was made to compare cricket with another mid-range sport in terms of popularity to avoid the profile of the sponsored property confounding findings in relation to brand equity. Several sponsors (from the financial services sector, to facilitate comparison), across a range of sports, were approached to take part in the study; however response was poor and thus the specific selection of athletics and cricket was made on the basis of willingness of both sponsor and sponsee to 
participate by allowing access to spectators at the events. In order to facilitate investigation of the effects of factors such as clutter, two established sponsorships were selected. The slightly differing lengths of sponsorship arrangement are noted as a limitation of the research, but the researchers were constrained in their ability to more tightly control differences between sponsorships by the reluctance of many proposed sponsors to grant access for data collection at sponsored events.

The choice of a cross-sectional survey methodology not only allows for comparisons to be made across sponsorship contexts but also attempts to overcome a prominent shortcoming of experimental research: the lack of generalizability to real-life market conditions. With a growing need among practitioners for evidence of sponsorship effectiveness, the collection of data in live sponsorship environments is an important contribution of this study. Collecting data in such environments is important as it assesses the effectiveness of sponsorship under prevailing market conditions; that is, the conditions under which consumers receive sponsorship messages, with the associated clutter and other elements fighting for consumer attention. As such the ecological validity (Gill and Johnson, 2002) of the study is increased, by more accurately representing the reality of consumer decision making and sponsorship exposure, compared with the controlled and isolated experimental conditions frequently used in previous research. It is acknowledged that by conducting research in real-life sponsorship settings, the design inevitably sacrifices elements of control over extraneous variables, such as the impact of additional marketing communications upon consumers (Gill and Johnson, 2002). However, by administering the questionnaire to both event-based and comparison samples within the same time 
period, attempts were made to control for exposure to other promotional tools, such as advertising.

The comparison groups represented a series of convenience samples from the membership list of an organisation known to the author. The group had no connection with any of the sporting events and contained a broad mix of ages and genders. Data was gathered from the comparison samples through self-administered postal questionnaires. With the exception of questions on sponsorship awareness, the questionnaire for the comparison sample was identical to that of the event-based sample to allow for direct comparison of brand equity scores. At each of the events, spectators were asked to complete a questionnaire either before or during breaks in play. In line with access rights awarded by sponsors/events to the researchers, data collection took place within the sporting arenas. Therefore, event-based respondents were in sight of sponsorship hoardings from all sponsors, not just those in this study. The lack of a pre-existing sampling frame prohibited the use of random sampling, therefore convenience sampling was used in order to maximise the number of responses in a constrained time period.

In comparing the event-based and comparison samples, it is not possible to know with certainty whether the two groups differ on any meaningful variables other than exposure to sponsorship (Black, 1999). However, as mentioned previously, such a trade-off is required if data is to be gathered in live market rather than experimental settings, thus enhancing the generalizability of results and differentiating this study from those conducted previously. 
Similarly, in comparing between different brands, there are inevitably differences between the sponsorship arrangements and conditions. Both brands in the study share the common characteristics of being the title sponsor of a UK sporting event but in order to explore the impact of clutter, it is necessary to compare across sports. Therefore, while acknowledging the shortcomings associated with a field survey methodology, comparison between events/sponsors is meaningful to advance our understanding of the impact of prevailing sponsorship environmental conditions on sponsorship effectiveness.

A modified version of the brand equity measurement tool developed by Aaker (1996) was employed to measure consumer-based brand equity. As outlined below, Aaker's (1996) measurement tool was modified during the course of a pilot study, producing a refined tool appropriate for the brands within this study and the data collection contexts. Several previous studies relating to sponsorship effectiveness from a managerial perspective have employed Aaker's (1996) model of consumer-based brand equity (Cornwell et al, 2001; Henseler et al, 2007). Therefore, this study adopts Aaker's framework in order to facilitate comparison between managerial and consumer perceptions. Aaker (1996) presents a series of measures of brand equity within the brand equity measurement tool, encompassing brand awareness, brand associations, perceived quality and brand loyalty. The measures were operationalised in line with the Aaker framework, resulting in the development of a multidimensional measure of consumer-based brand equity. The questionnaire was piloted at a Rugby League match, sponsored by a financial services company $(n=50)$, in order to test its suitability as a data collection tool within both the sporting event and sponsor product category context. Subsequently, the questionnaire was modified to reduce the length 
and improve the perceived ease of completion, in order to facilitate a higher response rate.

While presenting a comprehensive set of brand equity measures, Aaker (1996) acknowledges that not all measures will be suitable for all brands; thus the measures used were selected on the basis of suitability/relevance for the brands under investigation and their ability to effectively capture the key dimensions of consumerbased brand equity. The calculation of a price premium (an indicator of brand loyalty) was omitted as it was considered too onerous for respondents in the data collection setting. Similarly, the perceived quality element of 'consistent quality' was removed because this was deemed hard to evaluate for financial services brands, as the outcome of financial performance may not be known for a long time, e.g. when a policy matures. Other measures such as ‘admiration' (brand associations) and 'esteem' (perceived quality) were removed in order to reduce the length of the questionnaire, as they were deemed close substitutes of other measures such as 'trust' (brand associations) and 'respect' (perceived quality), while 'the brand is the only one/one of several I buy' (brand loyalty) was removed as this is less relevant in the financial services sector where purchase frequency is lower than, for example, FMCG markets. The final list of measures used is presented below in Table 1.

Table 1: Brand Equity Variables

\begin{tabular}{|l|l|l|l|}
\hline Brand Awareness & Brand Associations & Perceived Quality & Brand Loyalty \\
\hline Brand recognition & Trust & High quality & Expressed loyalty \\
\hline Product associations & Reasons to purchase & $\begin{array}{l}\text { Comparison with } \\
\text { competitors }\end{array}$ & $\begin{array}{l}\text { Satisfaction with } \\
\text { previous purchase }\end{array}$ \\
\hline Brand opinion & Differentiation & Leadership & Purchase intention \\
\hline & Distinctive personality & $\begin{array}{l}\text { Growing in } \\
\text { popularity }\end{array}$ & $\begin{array}{l}\text { Recommendation to } \\
\text { friends/family }\end{array}$ \\
\hline & Value for money & Innovation & Consideration \\
\hline & User image & Respect & Willingness to pay \\
\hline
\end{tabular}


\begin{tabular}{|l|l|l|l|}
\hline & & price premium \\
\hline
\end{tabular}

Both brands in this study are well-established and as shown in the results section, have very high levels of brand awareness across both the event-based and comparison samples, likely as a result of their historical investments in marketing communications. Therefore, while brand awareness is measured, given the high levels of base awareness, it is not meaningful to compare brand awareness scores across sample groups as building awareness is unlikely to have been an objective for the sponsors in this study.

The variables for brand associations, perceived quality and brand loyalty, along with brand opinion were measured using 5-point Likert scales from 'totally agree' to 'totally disagree' with a sixth category for 'don't know/not applicable'. The responses were scored from -2 (totally disagree) to +3 (totally agree) with 'neither agree nor disagree' scored as 1 and 'don't know/not applicable' scored as 0 . The rationale for this scoring system reflects the notion introduced in Aaker's (1991) conceptualisation of consumer-based brand equity that the equity can be positive or negative. The decision to score 'don't know' as lower than 'neither agree nor disagree' captures the difference between a neutral evaluation of a brand and a lack of brand knowledge. The key role played by brand knowledge in developing brand equity in the minds of consumers (Keller, 1993) is reflected in the inclusion of 'don't know' within the scaling of responses. Such responses are not meaningless but indicative of lower levels of brand equity. The scores for the individual variables were then combined to produce an overall score per respondent for brand associations, perceived quality and brand loyalty (ranging from -12 to +18 ), thus 
facilitating the use of t-tests to compare mean scores between the event-based samples and those not exposed to the sponsorship stimuli, in the comparison groups.

The Aaker (1996) tool has been previously validated and employed across a range of settings and while the headline categories of brand equity are broad, each individual indicator is reflective of the overall element (brand associations, perceived quality, brand loyalty), thus supporting their combining to produce cumulative scores. In addition, the internal reliability of the data collection instrument was tested across each event, with the individual scale items achieving an acceptable Cronbach's alpha score in excess of 0.7 in all cases (Henerson et al, 1987).

\subsection{Results and Discussion}

\subsection{Sample Profile}

Table 2 outlines the demographic profile of respondents at the two events, including, where marked, significant differences between sample groups on such variables. For the athletics sponsor, $51 \%$ of event-based and $62 \%$ of comparison sample respondents were male $\left(\chi^{2}(1)=4.066, p=0.044\right)$, with $51 \%$ of event-based respondents aged under 45 , compared with $41 \%$ of comparison sample respondents $(\chi 2(5)=20.295$, p $=0.001)$. A significant difference was also found between event-based and comparison sample respondents on the variable of household income $\left(\chi^{2}(5)=\right.$ 14.622, $\mathrm{p}=0.012$ ). For the cricket sponsor, $72 \%$ of event-based and $43 \%$ of comparison sample respondents were male $(\chi 2(1)=18.160, \mathrm{p}=0.000)$. However, no 
significant difference was found between event-based and comparison samples on age $\left(\chi^{2}(5)=9.628, \mathrm{p}=0.086\right)$ or household income $\left(\chi^{2}(5)=3.437, \mathrm{p}=0.633\right)$

Table 2 Demographic Data

\begin{tabular}{|l|l|l|l|l|}
\hline & \multicolumn{2}{|c|}{ Athletics Sponsorship } & \multicolumn{2}{c|}{ Cricket Sponsorship } \\
\hline & $\begin{array}{l}\text { Event-based } \\
\text { sample (\%) }\end{array}$ & $\begin{array}{c}\text { Comparison sample } \\
(\%)\end{array}$ & $\begin{array}{c}\text { Event-based } \\
\text { sample (\%) }\end{array}$ & $\begin{array}{c}\text { Comparison } \\
\text { sample (\%) }\end{array}$ \\
\hline Gender & $n=205$ & $n=141$ & $n=105$ & $n=102$ \\
\hline Male & 50.7 & 61.7 & 72.4 & 43.1 \\
\hline Female & 49.3 & 38.3 & 27.6 & 56.9 \\
\hline & \multicolumn{2}{|c|}{$\chi^{2}(1)=4.066, \mathrm{p}=0.044^{*}$} & \multicolumn{2}{c|}{$\chi^{2}(1)=18.160, \mathrm{p}=0.000^{*}$} \\
\hline Age & $n=205$ & $n=141$ & $n=106$ & $n=102$ \\
\hline $18-24$ & 8.8 & 15.6 & 10.4 & 3.9 \\
\hline $25-34$ & 20.0 & 9.9 & 10.4 & 8.8 \\
\hline $35-44$ & 22.4 & 15.6 & 12.3 & 23.5 \\
\hline $45-54$ & 17.6 & 33.3 & 22.6 & 13.7 \\
\hline $55-64$ & 22.9 & 18.4 & 20.8 & 25.5 \\
\hline $65+$ & 8.3 & 7.1 & 23.6 & 24.5 \\
\hline & \multicolumn{2}{|c|}{$\chi^{2}(5)=20.295, \mathrm{p}=0.001^{*}$} & \multicolumn{2}{c|}{$\chi^{2}(5)=9.628, \mathrm{p}=0.086$} \\
\hline Income & $n=168$ & $n=114$ & $n=89$ & $n=78$ \\
\hline Less than $£ 10000$ & 8.9 & 6.1 & 11.2 & 6.4 \\
\hline$£ 10001-£ 20000$ & 14.3 & 11.4 & 20.2 & 21.8 \\
\hline$£ 20001-£ 30000$ & 20.8 & 19.3 & 18.0 & 15.4 \\
\hline$£ 30001-£ 40000$ & 24.4 & 12.3 & 20.2 & 21.8 \\
\hline$£ 40001-£ 50000$ & 12.5 & 14.0 & 12.4 & 20.5 \\
\hline More than $£ 50001$ & 19.0 & 36.8 & 18.0 & 14.1 \\
\hline & \multicolumn{2}{|c|}{$\chi^{2}(5)=14.622, \mathrm{p}=0.012^{*}$} & & $\chi^{2}(5)=3.437, \mathrm{p}=0.633$ \\
\hline
\end{tabular}

*significant at $\mathrm{p}<0.05$

The lack of pre-existing sampling frames limited the ability to achieve matched samples in live sponsorship settings. While both financial services brands in this study offer a broad product portfolio, covering a wide target market, there is some empirical evidence to suggest that financial product purchase behaviour is impacted by both age and income (Tang et al, 2007). As such the lack of direct comparability between event-based and comparison sample demographic profiles represents a limitation of this study. 
The results obtained in terms of support for the proposed hypotheses vary between sponsors. Given the diverse nature of activities included under the banner of 'sponsorship,' such differential effects are unsurprising. Therefore, it is not possible to draw blanket conclusions regarding the contribution of sponsorship to brand equity. As such the remainder of this section will discuss the results relating to each hypothesis and, with reference to theoretical and empirical evidence discussed earlier, will propose reasons to explain the differential effectiveness of sponsorship in different contexts.

\subsection{Sponsorship and Brand Awareness}

Among event-based respondents, top-of-mind sponsorship awareness (i.e. first named sponsor) for the athletics sponsor was $78 \%$, indicating a very strong link between the sponsor and the sport. Aided awareness was 92\%, while event title sponsorship awareness was $95 \%$. In contrast, only $38 \%$ of respondents in the comparison sample were aware of any sponsorship activity by the brand. Therefore, the brand is clearly the dominant sponsor in athletics, in terms of pure visibility and sponsorship awareness amongst those present at events. Reinforcing the earlier contention, brand awareness for the athletics sponsor was very high among the event-based (99\%) and comparison samples $(98 \%)$.

The cricket sponsor achieved top-of-mind sponsorship awareness of 37\%; however, in total, 20 different brands were named as the first recalled cricket sponsor. Aided awareness of the brand's cricket sponsorship was $81 \%$, while $60 \%$ of event-based respondents correctly identified the brand as the event's title sponsor. Among the 
comparison sample, $48 \%$ of respondents were aware of some sponsorship activity by the brand. Brand awareness was $100 \%$ among both the event-based and comparison samples.

Across both brands, sponsorship awareness measures indicate the success of sponsorship at achieving brand visibility. Nonetheless, while aided awareness is generally high, sponsorship awareness for the cricket sponsor is much lower than that for the athletics sponsor, illustrating the difficulty of gaining prominence in a cluttered sponsorship environment. The collection of data from respondents in sight of sponsorship signage may have impacted on sponsorship awareness to some degree and this is noted as a caveat to the results presented here; however, the notable differences in title sponsorship awareness between the athletics and cricket sponsors indicates that the mere presence of signage does not necessarily lead to higher levels of sponsorship awareness. The high level of title sponsorship awareness for the athletics sponsor emphasises the strength of link between the sponsor and the event, which is a necessary condition for image transfer to occur (Smith, 2004). Therefore, while sponsorship awareness is only a preliminary measure towards brand equity, it can facilitate the formation of a strong sponsor-event link, which sets a platform from which sponsorship can impact the other elements of brand equity and allow the transfer of brand associations (Ko et al, 2008).

\subsection{Brand Associations $\left(\mathrm{H}_{1}\right)$}

As can be seen in Table 3, the mean score for the athletics sponsor for brand associations $(\mathrm{t}=4.004, \mathrm{p}=0.000)$ was significantly higher among those exposed to 
the sponsorship at the event than among the comparison sample. For the cricket sponsor, no significant difference was found between the samples on brand associations $(\mathrm{t}=1.834, \mathrm{p}=0.068)$; however using the non-parametric Mann Whitney $\mathrm{U}$ test, the mean score for those exposed to the sponsorship was found to be significantly higher than that for the comparison sample $(\mathrm{Z}=-2.218, \mathrm{p}=0.027)$. There is considerable debate as to whether data collected via Likert scale questions should be measured at the interval or ordinal level (Calder, 1996). Therefore, in this case, the non-parametric Mann Whitney U test was used in conjunction with parametric t-tests to provide a more robust test of the relevant hypotheses. Mann Whitney U tests were employed for all hypotheses in this study, but the results are only presented here in the case of a differential result between the parametric and nonparametric tests.

Table 3: Mean Brand Associations Scores

\begin{tabular}{|l|l|}
\hline Sample Group & Brand Associations \\
\hline Athletics Event & 5.7474 \\
\hline Athletics Comparison & 4.00 \\
\hline & $\begin{array}{l}\mathrm{t}=4.004 \\
\mathrm{p}=0.000\end{array}$ \\
\hline \multicolumn{2}{|l}{} \\
\hline Cricket Event & 4.9394 \\
\hline Cricket Comparison & 3.8367 \\
\hline & $\mathrm{t}=1.834$ \\
\hline
\end{tabular}

Hypothesis $\mathrm{H}_{1}$ is supported in the case of the athletics sponsor, while there is also some support for this hypothesis in the case of the cricket sponsor. In both cases, there is evidence that sponsorship exposure contributes significantly to the development of favourable brand associations. The creation of a strong link between the sponsor and the event facilitates the process of image transfer (Cornwell et al, 2005) and thus can explain the significantly higher brand associations score for those 
exposed to the sponsorship. These findings also support Nickell et al's (2011) hypothesis relating to the length of sponsorship arrangements, with the continued exposure to the sponsor-property link facilitating increased consumer affect towards the sponsoring brands.

Equally, support is found for Nickell et al's (2011) proposition of the importance of sponsorship leverage activities in impacting consumer attitudes to sponsoring brands. Both athletics and cricket sponsors used sponsorship as one part of a wider marketing communications strategy and the athletics sponsor, in particular, leveraged the sponsorship on-site through free gifts, product information leaflets and posters. Equally, both sponsoring brands leverage their respective sponsorships through grassroots sports initiatives and complement this with product-based television advertising. It is acknowledged that sponsorship may be poor at communicating detailed product information (Ukman, 2004); however, as the results of this empirical study illustrate, it can contribute to (intangible) image associations such as brand personality. Therefore, the results of this study thus support previous evidence on the necessity of effective sponsorship activation (Tripodi and Hurons, 2009; Cornwell et al, 2005).

Tables 4 and 5 present the results for the individual elements of brand associations for the athletics and cricket sponsors respectively.

Table 4: Mean Individual Brand Associations Element Scores (Athletics Sponsor)

\begin{tabular}{|l|l|l|l|}
\hline Attribute & $\begin{array}{c}\text { Event- } \\
\text { based } \\
\text { sample }\end{array}$ & $\begin{array}{c}\text { Comparison } \\
\text { sample }\end{array}$ & \\
\hline I trust [Sponsor] & 1.31 & 1.30 & $\mathrm{t}=0.082, \mathrm{p}=0.934$ \\
\hline [Sponsor] is different from other brands of & 0.69 & 0.38 & $\mathrm{t}=2.874, \mathrm{p}=0.004^{*}$ \\
\hline
\end{tabular}




\begin{tabular}{|l|l|l|l|}
\hline financial services & & & \\
\hline $\begin{array}{l}\text { There are definite reasons to buy } \\
\text { products/services from [Sponsor] rather than } \\
\text { other providers }\end{array}$ & 0.86 & 0.61 & $\mathrm{t}=2.217, \mathrm{p}=0.027^{*}$ \\
\hline The [Sponsor] brand has a distinctive personality & 1.12 & 0.74 & $\mathrm{t}=3.359, \mathrm{p}=0.001^{*}$ \\
\hline $\begin{array}{l}\text { [Sponsor] offers worse value for money than } \\
\text { other brands** }\end{array}$ & 1.00 & 0.79 & $\mathrm{t}=2.190, \mathrm{p}=0.029^{*}$ \\
\hline $\begin{array}{l}\text { I have a clear image of the type of person who } \\
\text { would use [Sponsor's] products/services }\end{array}$ & 0.73 & 0.25 & $\mathrm{t}=4.310, \mathrm{p}=0.000^{*}$ \\
\hline
\end{tabular}

*significant at $\mathrm{p}<0.05$

$* *$ Reverse scored to reflect negative wording of statement

Table 5: Mean Individual Brand Associations Element Scores (Cricket Sponsor)

\begin{tabular}{|l|l|l|l|}
\hline Attribute & $\begin{array}{l}\text { Event- } \\
\text { based } \\
\text { sample }\end{array}$ & $\begin{array}{l}\text { Comparison } \\
\text { sample }\end{array}$ & \\
\hline I trust [Sponsor] & 1.31 & 1.30 & $\mathrm{t}=0.116, \mathrm{p}=0.908$ \\
\hline $\begin{array}{l}\text { [Sponsor] is different from other brands of } \\
\text { financial services }\end{array}$ & 0.56 & 0.36 & $\mathrm{t}=1.332, \mathrm{p}=0.184$ \\
\hline $\begin{array}{l}\text { There are definite reasons to buy } \\
\text { products/services from [Sponsor] rather than } \\
\text { other providers }\end{array}$ & 0.65 & 0.50 & $\mathrm{t}=0.965, \mathrm{p}=0.336$ \\
\hline The [Sponsor] brand has a distinctive personality & 0.88 & 0.73 & $\mathrm{t}=0.932, \mathrm{p}=0.353$ \\
\hline $\begin{array}{l}\text { [Sponsor] offers worse value for money than } \\
\text { other brands** }\end{array}$ & 0.89 & 0.80 & $\mathrm{t}=0.680, \mathrm{p}=0.498$ \\
\hline $\begin{array}{l}\text { I have a clear image of the type of person who } \\
\text { would use [Sponsor's] products/services }\end{array}$ & 0.66 & 0.15 & $\mathrm{t}=3.429, \mathrm{p}=0.001^{*}$ \\
\hline I trust [Sponsor] & 1.31 & 1.30 & $\mathrm{t}=0.116, \mathrm{p}=0.908$ \\
\hline
\end{tabular}

*significant at $\mathrm{p}<0.05$

** Reverse scored to reflect negative wording of statement

As shown above, the athletics sponsor scored significantly higher among those exposed to the sponsorship than among the comparison sample, on the individual brand associations dimensions of differentiation, reason to purchase, distinctive personality, value for money and user image. Notably, the significant impact on differentiation is vital, particularly for financial services providers, as many financial product offerings are relatively homogeneous, meaning that other sources of differentiation are required for a brand to stand out from its competitors (Amis et al, 1999). The notion of exclusivity and the implied link to using sponsorship as a source of differentiation is highly prized by sponsors (Copeland et al, 1996). Therefore, 
there is empirical evidence from this study that through the creation of intangible image associations (facilitated by a strong sponsor-event link), brands can use sponsorship as a point of competitive differentiation (Amis et al, 1997).

In contrast, no significant difference between the event-based and comparison samples was found for the cricket sponsor on the dimension of differentiation from competitors. Unlike the case of athletics where there is only one major financial services sponsor, the cluttered environment of cricket sponsorship is not a point of competitive differentiation for the brand in question. The differential impact on perceived differentiation from competitors in this study represents a notable clarification on existing understanding of the influences on sponsorship success. While both sponsorships are of an established nature, this alone does not appear to guarantee sponsorship as a source of differential competitive advantage. There is also a requirement to avoid cluttered environments, particularly those where competitors are also present, in order for sponsorship to be perceived as a unique resource and thus be used to distinguish a sponsoring brand from its competitors. The cluttered sponsorship environment has further implications for the cricket sponsor, as evidenced by the lack of significant impact of sponsorship on perceived quality.

\subsection{Perceived Quality $\left(\mathrm{H}_{2}\right)$}

As shown below in Table 6 , for the athletics sponsor, the mean perceived quality score was significantly higher for those exposed to the sponsorship at the event than those in the comparison sample $(t=2.421, \mathrm{p}=0.016)$. No significant difference was found between the sample groups for the cricket sponsor for perceived quality $(\mathrm{t}=$ 
$1.100, \mathrm{p}=0.273)$. Thus, support was found for hypothesis $\mathrm{H}_{2}$ in the case of the

athletics sponsor, but not the cricket sponsor.

Table 6 Mean Perceived Quality Scores

\begin{tabular}{|l|l|}
\hline Sample Group & Perceived Quality \\
\hline Athletics Event & 7.3089 \\
\hline Athletics Comparison & 6.2574 \\
\hline & $\mathrm{t}=2.421$ \\
& $\mathrm{p}=0.016$ \\
\hline \multicolumn{2}{|l}{} \\
\hline Cricket Event & 6.375 \\
\hline Cricket Comparison & 5.6733 \\
\hline & $\mathrm{t}=1.100$ \\
& $\mathrm{p}=0.273$ \\
\hline
\end{tabular}

Tables 7 and 8 present the results for the individual elements of perceived quality for the athletics and cricket sponsors respectively.

Table 7 Mean Individual Perceived Quality Element Scores (Athletics Sponsor)

\begin{tabular}{|l|l|l|l|}
\hline Attribute & $\begin{array}{c}\text { Event- } \\
\text { based } \\
\text { sample }\end{array}$ & $\begin{array}{l}\text { Comparison } \\
\text { sample }\end{array}$ & \\
\hline [Sponsor] is of high quality & 1.44 & 1.48 & $\mathrm{t}=-0.392, \mathrm{p}=0.696$ \\
\hline [Sponsor] is a brand I respect & 1.42 & 1.41 & $\mathrm{t}=0.097, \mathrm{p}=0.923$ \\
\hline [Sponsor] is a leader in financial services & 1.23 & 0.90 & $\mathrm{t}=2.978 \mathrm{p}=0.003^{*}$ \\
\hline [Sponsor] is a brand that is growing in popularity & 1.12 & 0.84 & $\begin{array}{l}\mathrm{t}=3.155, \mathrm{p}= \\
0.002^{*}\end{array}$ \\
\hline $\begin{array}{l}\text { [Sponsor] offers innovative products and services } \\
\mathrm{l}\end{array}$ & 0.90 & 0.70 & $\begin{array}{l}\mathrm{t}=2.279, \mathrm{p}= \\
0.023^{*}\end{array}$ \\
\hline $\begin{array}{l}\text { Compared to other brands of financial services, } \\
\text { [Sponsor] is [5 point scale from 'the best' to 'the } \\
\text { worst' plus 'don't know' option] }\end{array}$ & 1.10 & 0.94 & $\mathrm{t}=1.660, \mathrm{p}=0.098$ \\
\hline
\end{tabular}

*significant at $\mathrm{p}<0.05$

Table 8 Mean Individual Perceived Quality Element Scores (Cricket Sponsor)

\begin{tabular}{|l|l|l|l|}
\hline Attribute & $\begin{array}{l}\text { Event- } \\
\text { based } \\
\text { sample }\end{array}$ & $\begin{array}{l}\text { Comparison } \\
\text { sample }\end{array}$ & \\
\hline [Sponsor] is of high quality & 1.42 & 1.26 & $\mathrm{t}=1.205, \mathrm{p}=0.230$ \\
\hline [Sponsor] is a brand I respect & 1.34 & 1.26 & $\mathrm{t}=0.065, \mathrm{p}=0.948$ \\
\hline [Sponsor] is a leader in financial services & 1.17 & 0.99 & $\mathrm{t}=1.108, \mathrm{p}=0.269$ \\
\hline [Sponsor] is a brand that is growing in popularity & 0.80 & 0.63 & $\mathrm{t}=1.194, \mathrm{p}=0.234$ \\
\hline
\end{tabular}




\begin{tabular}{|l|l|l|l|}
\hline $\begin{array}{l}\text { [Sponsor] offers innovative products and } \\
\text { services }\end{array}$ & 0.75 & 0.60 & $\mathrm{t}=1.221, \mathrm{p}=0.224$ \\
\hline $\begin{array}{l}\text { Compared to other brands of financial services, } \\
\text { [Sponsor] is [5 point scale from 'the best' to 'the } \\
\text { worst' plus 'don't know' option] }\end{array}$ & 0.91 & 0.83 & $\mathrm{t}=0.434, \mathrm{p}=0.665$ \\
\hline
\end{tabular}

*significant at $\mathrm{p}<0.05$

A key difference between the athletics and cricket sponsorship environments concerns the levels of sponsorship clutter. Clutter has been found to negatively impact upon brand recall (Keller, 1991; Cornwell et al, 2006), explaining the lower title sponsorship awareness of the cricket sponsor. As such, the link from the sponsor to the event is weaker, which may inhibit the transfer of the associations of quality sought by the cricket sponsor. Tellingly, in relation to the hypothesised relationship between sponsorship and perceived quality, the athletics sponsor scored significantly higher among the event-based sample on the perceived quality dimension of leadership, while no significant difference was found for the cricket sponsor. As implied in Smith's (2004) model of brand image transfer, as the dominant sponsor in UK athletics, the prestige of being a leading sponsor 'rubs off' on the brand, while, when faced with large amounts of clutter, it is not possible for the cricket sponsor to tap these associations of leadership through its sponsorship. The high profile and ubiquity achieved by the athletics sponsor in its link with the sport enables connotations of superiority and leadership to be transferred to the brand through sponsorship. The conceptual jump for consumers from number one athletics sponsor to a leader in its field is not as great as it would be for the cricket sponsor, as one of many financial services brands involved in cricket. The absence of clutter over the length of the athletics sponsorship, facilitating this transfer of associations of leadership, has contributed to a higher perceived quality score and reinforced the fit between the sponsor and the event. Highlighting the importance of fit as a 
determinant of sponsorship effectiveness (Simmons and Becker-Olsen, 2006), the exclusivity enables the formation of the leadership associations, which in turn enhance the sponsor-event fit, thus facilitating further image transfer. Over time, this strong sponsor-event fit thus results in the sponsorship becoming a sustainable source of competitive differentiation and advantage.

\subsection{Brand Loyalty $\left(\mathrm{H}_{3}\right)$}

As shown below in Table 9, for the athletics sponsor, the mean brand loyalty score was significantly higher for those exposed to the sponsorship at the event than those in the comparison sample $(\mathrm{t}=2.996, \mathrm{p}=0.003)$. In the case of the cricket sponsor, the mean score among the event-based sample was significantly higher than that in the comparison sample for brand loyalty $(t=2.611, p=0.010)$. Therefore, in both cases, support is found for hypothesis $\mathrm{H}_{3}$, indicating that sponsorship exposure can lead to increased levels of brand loyalty.

Both of the brands complement their respective elite sponsorships through a range of grassroots initiatives, such as coaching clinics for children. By adopting an integrated approach to sponsorship, it is possible to engender a sense that by supporting the sponsor, customers are indirectly contributing to the development of their favourite sport. As such, the depth of sponsorship at all levels through sport may account for the ability of sponsorship to build attitudinal brand loyalty.

Table 9 Mean Brand Loyalty Scores

\begin{tabular}{|l|l|}
\hline Sample Group & Brand Loyalty \\
\hline Athletics Event & 4.8469 \\
\hline Athletics Comparison & 3.3456 \\
\hline
\end{tabular}




\begin{tabular}{|c|c|}
\hline & $\begin{array}{l}\mathrm{t}=2.996 \\
\mathrm{p}=0.003\end{array}$ \\
\hline Cricket Event & 3.7184 \\
\hline Cricket Comparison & 1.7347 \\
\hline Sample Group & $\begin{array}{l}t=2.611 \\
p=0.010\end{array}$ \\
\hline
\end{tabular}

As discussed above, both athletics and cricket sponsors enjoyed a significant impact of their respective sponsorships on brand associations. By impacting upon brand associations, sponsorship can endow a brand with properties with which consumers wish to be associated, for example a positive user image. Thus, the sponsors become brands with which the consumers wish to develop a relationship. Therefore, the ability of sponsorship to develop intangible brand associations may be the key to enhancing brand loyalty. This proposition represents an area worthy of future investigation in the search for understanding of how sponsorship impacts upon consumer behaviour.

Tables 10 and 11 present the results for the individual elements of brand loyalty for the athletics and cricket sponsors respectively.

Table 10 Mean Individual Brand Loyalty Element Scores (Athletics Sponsor)

\begin{tabular}{|l|l|l|l|}
\hline Attribute & $\begin{array}{c}\text { Event- } \\
\text { based } \\
\text { sample }\end{array}$ & $\begin{array}{l}\text { Comparison } \\
\text { sample }\end{array}$ & \\
\hline I feel loyal to [Sponsor] & 0.70 & 0.21 & $\mathrm{t}=3.740, \mathrm{p}=0.000^{*}$ \\
\hline $\begin{array}{l}\text { I was satisfied with [Sponsor] the last time I } \\
\text { purchased a product or service from the company }\end{array}$ & 1.11 & 1.19 & $\mathrm{t}=-0.712, \mathrm{p}=0.477$ \\
\hline $\begin{array}{l}\text { I would recommend [Sponsor] to my friends and } \\
\text { family }\end{array}$ & 0.92 & 0.83 & $\mathrm{t}=0.718, \mathrm{p}=0.474$ \\
\hline $\begin{array}{l}\text { I intend to purchase products/services from } \\
\text { [Sponsor] in the future }\end{array}$ & 0.82 & 0.46 & $\mathrm{t}=3.109, \mathrm{p}=0.002^{*}$ \\
\hline $\begin{array}{l}\text { I would be willing to pay a higher price for } \\
\text { [Sponsor] products/services over other competing } \\
\text { brands }\end{array}$ & -0.18 & -0.66 & $\mathrm{t}=3.746, \mathrm{p}=$ \\
\hline When I am looking for a financial services & 1.47 & 1.33 & $\mathrm{t}=1.2000^{* * *}$ \\
\hline
\end{tabular}


provider, I will consider [Sponsor]

*significant at $\mathrm{p}<0.05$

*** While a significant difference was found on 'willingness to pay a higher price', the mean score was negative, indicating no support for a price premium.

Table 11 Mean Individual Brand Loyalty Element Scores (Cricket Sponsor)

\begin{tabular}{|l|l|l|l|}
\hline Attribute & $\begin{array}{c}\text { Event- } \\
\text { based } \\
\text { sample }\end{array}$ & $\begin{array}{l}\text { Comparison } \\
\text { sample }\end{array}$ & \\
\hline I feel loyal to [Sponsor] & 0.67 & 0.23 & $\mathrm{t}=2.478, \mathrm{p}=0.014^{*}$ \\
\hline $\begin{array}{l}\text { I was satisfied with [Sponsor] the last time I } \\
\text { purchased a product or service from the company }\end{array}$ & 0.86 & 0.65 & $\mathrm{t}=1.312, \mathrm{p}=0.191$ \\
\hline $\begin{array}{l}\text { I would recommend [Sponsor] to my friends and } \\
\text { family }\end{array}$ & 0.85 & 0.49 & $\mathrm{t}=2.272, \mathrm{p}=0.024^{*}$ \\
\hline $\begin{array}{l}\text { I intend to purchase products/services from } \\
\text { [Sponsor] in the future }\end{array}$ & 0.50 & 0.21 & $\mathrm{t}=1.808, \mathrm{p}=0.072$ \\
\hline $\begin{array}{l}\text { I would be willing to pay a higher price for } \\
\text { [Sponsor] products/services over other competing } \\
\text { brands }\end{array}$ & -0.39 & -0.91 & $\begin{array}{l}\mathrm{t}=3.381, \mathrm{p}= \\
0.001 * * *\end{array}$ \\
\hline $\begin{array}{l}\text { When I am looking for a financial services } \\
\text { provider, I will consider [Sponsor] }\end{array}$ & 1.21 & 1.05 & $\mathrm{t}=0.954, \mathrm{p}=0.341$ \\
\hline
\end{tabular}

*significant at $\mathrm{p}<0.05$

*** While a significant difference was found on 'willingness to pay a higher price', the mean score was negative, indicating no support for a price premium.

While both sponsors scored significantly higher among event-based respondents on the individual attitudinal loyalty dimension of purchase intention, no substantive impact was found for either brand on the behavioural element of willingness to pay a price premium. This is unsurprising for financial services brands, with the importance of price as a purchase criterion and the prevalence of negative loyalty as a result of inertia or high perceived switching costs (Harrison, 2000). Nonetheless, in the case of the athletics sponsor, sponsorship has built positive quality associations; thus if the brand can match competitors on price, the intangible image associations achieved through the sponsorship may lead to increased sales by providing a point of competitive differentiation (Amis et al, 1999) in a highly homogeneous market. 


\subsection{Managerial Implications}

This study has reinforced, within real-life sponsorship settings, previous findings relating to factors affecting the impact of sponsorship on consumer-based brand equity, notably examining the combination of factors under prevailing sponsorship market conditions. Therefore, the study contributes to our understanding of the factors affecting sponsorship's ability to deliver a sustainable competitive advantage. By offering evidence from the live sponsorship settings under which sponsors will be operating, the results also have practical significance for sponsors when making sponsorship investment decisions. The results support the theoretical propositions that the avoidance of cluttered environments and the use of sponsorship activation tactics are crucial if sponsorship is to achieve much sought objectives relating to building brand equity. In particular, in order to use sponsorship to build a perception of quality, the findings suggest that sponsors must either select an exclusive, but potentially expensive, sponsorship, or develop the sponsorship through avoiding cluttered environments. In order to build brand associations, the results from this study suggest that sponsors must first forge a strong link to the event, through supporting advertising and other promotions, and then exploit this by using integrated sponsorship activation programs, so as to distinguish the brand from fellow sponsors (Amis et al, 1999). Similarly, based on the findings of this study in relation to brand loyalty, the development of an integrated sponsorship campaign at all levels of sport is crucial for brands seeking to nurture loyalty, by demonstrating a wider commitment to sport and local communities. Such activities allow sponsors the opportunity to 
highlight to consumers the relevance and contribution of their sponsorships, fostering among consumers a desire to be associated with such brands.

\subsection{Limitations of the Study and Areas for Future Research}

This study has focused entirely upon sports event sponsorship; therefore no claim is made for generalizability to other contexts, such as team or venue sponsorship. The unique characteristics of financial services brands in terms of patterns of loyalty and consumer response may have impacted on the results obtained in this study; therefore no claim is made of generalizability to other sponsor product categories. Nonetheless, given the prevalence of financial services sponsorship in the UK (Mintel, 2011b), this industry was deemed important to investigate. However, having identified an appropriate evaluation methodology, a fruitful area for future research lies in replicating this study in different sponsorship settings in order to identify whether the identified contextual factors also play a role outside of event sponsorship and for different sports/sponsor product categories.

A limitation of this study was the use of non-random samples; also, the sample size was, at times, limited by the resources available. Therefore, a further area of future research is to replicate the study with larger samples and in an experimental setting in order to control for extraneous variables such as exposure to other marketing communications activity.

\subsection{Conclusions}


The results presented in this study have highlighted that sponsorship can have a positive impact on all areas of consumer-based brand equity. However, there are several contextual elements which are crucial to achieving success through sponsorship. Consequently, the results presented here provide support for previous studies identifying factors impacting on sponsorship's brand equity building effectiveness, notably the development of a strong sponsor-event link, effective leverage and using sponsorship as part of a wider programme of marketing communications, and the avoidance of cluttered environments. Through this, the study also builds on previous theoretical work, providing empirical evidence for the ability of sponsorship, under certain conditions, to act as a source of differential competitive advantage.

Distinct from many previous investigations, and providing the key contribution of the research, this study was conducted among consumers in real-life sporting event settings. By identifying the brand-building role of sponsorship and the factors impacting upon its effectiveness under prevailing market and environmental conditions, this study reinforces previous experimental and theoretical work and extends our understanding of the impact of these factors when in combination. The scope of activities possible under the banner of sponsorship makes the development of a generic, one-size-fits-all model difficult to achieve. Therefore, it is necessary to modify existing marketing communications evaluation tools in order to accommodate the context-specific elements inherent in individual sponsorships. The findings from this study can thus inform the future development of models of how sponsorship works. 


\subsection{References}

Aaker, D. A. (1991) Managing Brand Equity. Capitalizing on the value of a brand name. New York, Free Press.

Aaker, D. A. (1996). Measuring brand equity across products and markets. California Management Review, 38 (3), 102-120.

Abratt, R., Clayton, B. C. and Pitt, L. F. (1987). Corporate objectives in sports sponsorship. International Journal of Advertising, 6 (4), 299-311.

Amis, J., Pant, N. and Slack, T. (1997) Achieving a Sustainable Competitive Advantage: A Resource-Based view of Sport Sponsorship. Journal of Sport Management 11 (1), 80-96.

Amis, J., Slack, T. and Berrett, T. (1999). Sport sponsorship as distinctive competence. European Journal of Marketing, 33 (3/4), 250-272.

Anantachart, S. (2005) Integrated Marketing Communications and Market Planning: Their Implications to Brand Equity Building, Journal of Promotion Management 11(1), 101125.

Becker-Olsen, K.L. and Hill, R.P. (2006). The Impact of Sponsor Fit on Brand Equity: The Case of Nonprofit Service Providers. Journal of Service Research 9 (1), $73-83$ 
Bennett, R. (1999). Sports sponsorship, spectator recall and false consensus.

European Journal of Marketing, 33 (3/4), 291-313.

Black, T. R. (1999). Doing quantitative research in the social sciences. London, Sage.

Busby, R. (1997). Managing successful sponsorship. London, Financial Times.

Calder, J. (1996). Statistical Techniques. In R. Sapsford and V. Jupp (eds) Data Collection and Analysis. London, Sage, 225-261.

Copeland, R., Frisby, W. and McCarville, R. (1996). Understanding the sport sponsorship process from a corporate perspective. Journal of Sport Management, 10 (1), 32-48.

Cornwell, T.B (2008) State of the art and science in sponsorship-linked marketing. Journal of Advertising, 37 (3), 41-55.

Cornwell, T.B, Humphreys, M.S, Maguire, A.M, Weeks, C.S and Tellegen, C.L (2006) Sponsorship-linked marketing: The role of articulation in memory. Journal of Consumer Research, 33 (3), 312-321.

Cornwell, T. B., Roy, D. P. and Steinard, E. A. (2001). Exploring managers' perceptions of the impact of sponsorship on brand equity. Journal of Advertising, 30 (2), 41-51. 
Cornwell, T.B., Weeks, C.S. and Roy, D. P. (2005) Sponsorship-linked marketing: opening the black box, Journal of Advertising 34(2), 21-42.

Dees, W., Bennett, G. and Ferreira, M. (2010) Personality fit in NASCAR: an evaluation of driver-sponsor congruence and its impact on sponsorship effectiveness outcomes, Sport Marketing Quarterly 19(1), 25-35.

Dees, W., Bennett, G. and Villegas, J. (2008) Measuring the effectiveness of sponsorship of and elite intercollegiate football program. Sport Marketing Quarterly 17 (2), 79-89.

Gill, J. and Johnson, P. (2002). Research methods for managers. 3rd ed., London, Sage.

Grohs, R. and Reisinger, H. (2005). Image transfer in sports sponsorship: an assessment of moderating effects. International Journal of Sports Marketing \& Sponsorship 7 (1), 42-48.

Gwinner, K. (1997). A model of image creation and image transfer in event sponsorship. International Marketing Review, 14 (3), 145-158.

Harrison, T. (2000). Financial Services Marketing. Harlow, Essex, Pearson Education. 
Hartland, T., Skinner, H. and Griffiths, A. (2005) "Tries and conversions: are sports sponsors pursuing the right objectives?” International Journal of Sports Marketing \& Sponsorship 6 (3), 164-173.

Harvey, B. (2001) Measuring the effects of sponsorship. Journal of Advertising Research 41 (1), 59-65.

Helgesen, Ø. (2006) Are loyal customers profitable? Customer satisfaction, customer (action) loyalty and customer profitability at the individual level. Journal of Marketing Management, 22 (3/4), 245-266.

Henerson, M. E., Morris, L. L. and Fitz-Gibon, C. T. (1987). How to measure attitudes. Newbury Park, CA, Sage.

Henseler, J., Wilson, B., Götz, O. and Hautvast, C. (2007). Investigating the moderating role of fit on sports sponsorship and brand equity. International Journal of Sports Marketing \& Sponsorship 8 (4), 321-329.

Hoek, J., Gendall, P., Jeffcoat, M. and Orsman, D. (1997). Sponsorship and advertising: A comparison of their effects. Journal of Marketing Communications, 3 (1), 21-32.

IEG., (2013). 2013 sponsorship outlook: spending increase is double-edged sword Available at: http://www.sponsorship.com/iegsr/2013/01/07/2013-Sponsorship$\underline{\text { Outlook--Spending-Increase-Is- }}$ 
Dou.aspx?utm_source=NewsPage\&utm_medium=PremiumContentSummary\&utm_t

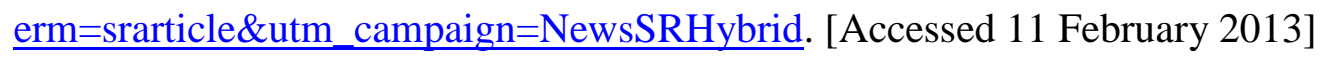

Javalgi, R. G., Traylor, M. B., Gross, A. C. and Lampman, E. (1994). Awareness of sponsorship and corporate image: An empirical investigation. Journal of Advertising, $23(4), 47-58$.

Johar, G. V. and Pham, M. T. (1999). Relatedness, prominence, and constructive sponsor identification. Journal of Marketing Research, 36 (3), 299-312.

Keller, K. L. (1993). Conceptualizing, measuring, and managing customer-based brand equity, Journal of Marketing, 57 (1), 1-22.

Keller, K.L. (1991). Memory and Evaluation Effects in Competitive Advertising Environments. Journal of Consumer Research 17 (4), 463-476.

Kim, Y. (2001). The impact of brand equity and the company's reputation on revenues, Journal of Promotion Management 6 (1-2), 89-111.

Ko, Y.J., Kim, K., Claussen, C.L. and Kim, T.H. (2008). The effects of sport involvement, sponsor awareness and corporate image on intention to purchase sponsors' products. International Journal of Sports Marketing \& Sponsorship 9 (2), 79-94. 
Levin, A. M., Beasley, F. and Gamble, T. (2004). Brand loyalty of NASCAR fans towards sponsors: The impact of fan identification. International Journal of Sports Marketing \& Sponsorship, 6 (1), 11-21.

Martensen, A., Grønholt, L., Bendtsen, L. and Jensen, M.J. (2007). Application of a model for the effectiveness of event marketing, Journal of Advertising Research 47 (3), 283-301.

Mason, K. (2005) How corporate sport sponsorship impacts consumer behaviour. The Journal of American Academy of Business, Cambridge 7 (1), 32-35.

Maxwell, H. and Lough, N. (2009) Signage vs. No-Signage: An Analysis of Sponsorship Recognition in Women's College Basketball. Sport Marketing Quarterly $18(4), 188-198$.

McCook, K., Turco, D. and Riley, R. (1997) A look at the corporate sponsorship decision-making process, The Cyber Journal of Sport Marketing 1 (2) Available at: http://fulltext.ausport.gov.au/fulltext/1997/cjsm/v1n2/mcook.htm [Accessed 24 February 2012]

Mintel (2011a) Spectator Sports - UK - April 2011. London, Mintel Group.

Mintel (2011b) Sports Marketing and Sponsorship - UK - June 2011. London, Mintel Group. 
Nickell, D., Cornwell, T.B. and Johnston, W.J. (2011) Sponsorship-linked marketing: a set of research propositions, Journal of Business \& Industrial Marketing 26 (8), $577-589$.

Nufer, G. and Bühler, A. (2010) How effective is the sponsorship of global sports events? A comparison of the FIFA World Cups in 2006 and 1998, International Journal of Sports Marketing \& Sponsorship 11 (4), 303-319.

Palazón-Vidal, M and Delgado-Ballester, E (2005) Sales promotions effects on consumer-based brand equity, International Journal of Market Research 47(2) pp. 179-204.

Papadimitriou, D. and Apostolopoulou, A. (2009). Olympic sponsorship activation and the creation of competitive advantage, Journal of Promotion Management 15 (1/2), 90-117.

Payne, M. (2005). Olympic turn around. Twyford, Berkshire, London Business Press

Performance Research., (2003). Sponsor loyalty left by roadside Available at: http://www.performanceresearch.com/f1-sponsor-loyalty.htm. [Accessed 28 February 2012]

Pham, M. T. and Johar, G. V. (2001). Market prominence biases in sponsor identification: Processes and consequentiality. Psychology \& Marketing, 18 (2), 123 143. 
Poon, D.T.Y. and Prendergast, G. (2006) A new framework for evaluating sponsorship opportunities, International Journal of Advertising 25 (4), 471-488.

Pope, N., Voges, K.E. and Brown, M. (2009). Winning Ways. Immediate and longterm effects of sponsorship on perceptions of brand quality and corporate image, Journal of Advertising 38 (2), 5-20.

Pope, N. K. and Voges, K. E. (1994). Sponsorship evaluation: Does it match the motive and the mechanism? Sport Marketing Quarterly, 3 (4), 37-45.

Quester, P. G. (1997). Awareness as a measure of sponsorship effectiveness: The Adelaide Formula One Grand Prix and evidence of incidental ambush effects. Journal of Marketing Communications, 3 (1), 1-20.

Rindfleisch, A., Malter, A.J., Ganesan, S. and Moorman, C. (2008). Cross-Sectional Versus Longitudinal Survey Research: Concepts, Findings, and Guidelines. Journal of Marketing Research, 45 (3), 261-279

Rines, S. (2002). Guinness Rugby World Cup sponsorship: A global platform for meeting business objectives. International Journal of Sports Marketing \& Sponsorship, 3 (4), 449-465.

Roy, D. P. and Cornwell, T. B. (2004). The effects of consumer knowledge on responses to event sponsorships. Psychology \& Marketing, 21 (3), 185-207. 
Roy, D. P. and Cornwell, T. B. (1999). Managers' use of sponsorship in building brands: Service and product firms contrasted. International Journal of Sports Marketing \& Sponsorship, 1 (4), 345-359.

Simmons, C.J. and Becker-Olsen, K.L. (2006). Achieving marketing objectives through social sponsorship, Journal of Marketing 70 (4), 154-169.

Sirgy, M.J., Lee, D-L., Johar, J.S. and Tidwell, J. (2008) Effect of self-congruity with sponsorship on brand loyalty, Journal of Business Research 61 (10), 1091-1097.

Skildum-Reid, K., (2003). Last Generation Sponsorship Available at: http://www.powersponsorshipdownloads.com/powersponsorship/LastGenerationSpon sorship.pdf [Accessed 8 February 2013].

Smith, G. (2004). Brand image transfer through sponsorship: A consumer learning perspective. Journal of Marketing Management, 20 (3/4), 457-474.

Tang, L., Thomas, L.C., Thomas, S. and Bozzetto, J-F. (2007) It's the economy stupid: Modelling financial product purchases. International Journal of Bank Marketing 25 (1), 22-38.

Tomasini, N., Frye, C. and Stotlar, D. (2004). National Collegiate Athletic Association Corporate Sponsor Objectives: Are There Differences Between Divisions I-A, I-AA, and I-AAA? Sport Marketing Quarterly 13 (4), 216-226. 
Too, L. H. Y., Souchon, A. L. and Thirkell, P. C. (2001) Relationship marketing and customer loyalty in a retail setting: A dyadic exploration. Journal of Marketing Management, 17 (3/4), 287-319.

Tripodi, J.A. and Hirons, M. (2009) Sponsorship leveraging case studies - Sydney 2000 Olympic Games, Journal of Promotion Management 15 (1/2), 118-136.

Ukman, L. (2004). IEG's guide to sponsorship Chicago, IEG.

Verity, J. (2002). Maximising the marketing potential of sponsorship for global brands. European Business Journal, 14 (4), 161-173.

Walliser, B. (2003). An international review of sponsorship research: Extension and update. International Journal of Advertising, 22 (1), 5-40.

Washburn, J. H. and Plank, R. E. (2002). Measuring brand equity: An evaluation of a consumer-based brand equity scale. Journal of Marketing Theory and Practice, 10 (1), 46-61.

Weeks, C.S., Cornwell, T.B. and Drennan, J.C. (2008). Leveraging sponsorship on the Internet: activation, congruence and articulation, Psychology \& Marketing 25 (7), 637-654. 